\title{
Fastness Properties of Colorant Extracted from Locust Beans Fruits Pods to Dye Cotton and Silk Fabrics
}

\author{
Ibrahim Abdullahi Umar \\ Faculty of Creative Technology and Heritage, University Malaysia Kelantan, Malaysia \\ Tel: 60-1-116-323-023 E-mail: ibrahimhinna@ymail.com \\ Mohammed Najib bn Muh'd nor \\ Faculty of Creative Technology and Heritage, University Malaysia Kelantan, Malaysia \\ Tel: 60-1-9319-1973Ｅ-mail: najib@umk.edu.my
}

\author{
Wong Y. C. \\ Faculty of Agro Based Industry, University Malaysia Kelantan, Malaysia \\ Tel: 60-1-2960-3887Ｅ-mail: yeeching@umk.edu.my
}

Received: February 1, 2013 Accepted: February 25, 2013

doi:10.5296/emsd.v2i1.3228 URL: http://dx.doi.org/10.5296/emsd.v2i1.3228

\begin{abstract}
This study investigates the extraction of colour from locust beans fruits pods to dye cotton and silk fabrics using the mordanting treatment with these mordants of CUSO4, FERROUS (II) \& (III) SULPHATE AND ALUM. Aqueous and solvent extraction method was adopted for this experiment. The colour obtained was different shades ranging from soft, light brown and brown, depending on the mordant used. However, the change in colour can be improved using other mordant from the ones used in this study, fastness properties test was carried out and proved good result. Therefore, the findings will benefit local dyers, farmers, textiles industries; organisations, institutions that deal with dyes/colour, research institutes and can be good for future research on other natural fabrics.
\end{abstract}

Keywords: Aqueous and solvent Extraction method, Colour/dye, locust beans pods, Cotton and Silk Fabrics, Dyed, Fastness test 


\section{Introduction}

The use of natural colors for dyeing fabrics has been in practice since ancient times, where most of the dye color are obtained from the plants parts (leaves, flowers, stem, roots, fruits and pods (Adeel et al, 2009; Kanez, 2004). The advent of synthetic dyes during 1856-1900 jeopardized the market of natural colorants, as synthetic dyes were cheaper and gave excellent fastness and reproducible color shades (Samanta \& Konar, 2012).

The growing awareness of environmental problems coupled with the toxicity associated with synthetic dyes, brings back the promising prospects of nature to the cheaper extraction technology of colorants from natural, renewable resources plants parts (Kulkarni, 2011).

It is on this footstep of global concern over the use of an eco-friendly and biodegradability of natural materials that this research work bends on one of the famous plant known as locust beans (An Answer to Africa's Greatest Needs in One Tree) also refers to as(parkia biglobosa/filicoidea). It is a multipurpose tree which is cultivated over a wide area in the world, especially within the African sub region, it occurs in large numbers, from the Atlantic coast in Senegal to Sudan and northern Uganda, (Sina and Traore, 2002). In Africa, the Western Sahara and Nigeria in particular the plants play a vital role in making food delicacy as well as commerce, but the exploitation have not been done as a means of natural dyes (Figure a, b,\& c) 1.1 Heading Level-2
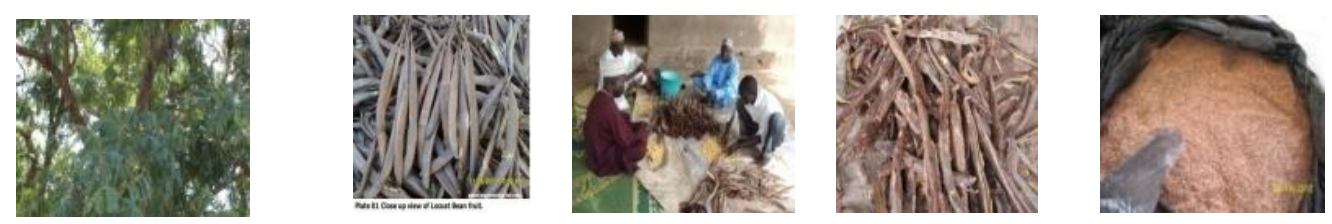

Figure $1 \mathrm{a}, \mathrm{b} \& \mathrm{c}$ locust beans tree $\&$ the fruits being open to get the pods in powder form.

The locust beans fruit(pods) after de-hauling the empty pods are thrown away in most places in west Africa especially in the northern Nigeria, and this also contribute negatively to the environment, but nevertheless research efforts are geared towards possible ways of recycling these waste for re-use to keep the environment clean and safe.

The small and medium scale industries have the greatest potential for this re-use of the husk pods because they use large quantities of natural materials annually stated by (Emhammed Basha, Roslam Hashim \& Muntohar, 2002). Also reported by (Jimoh \& Adamu, retrieved 4 may 2012) that the extract can be obtained when the pods husks is boil in water, a reddish brown colour is usually obtained which have been used only for mixing clay tiles for local flooring construct and finishes.

It is now evidence based on this extract of brown colour from the locust beans pods fruit pods that this research work focus on exploring the reddish brown colour to be re-used as natural colour/dyes and only fastness properties of this colorant on fabric especially on natural fabrics such as cotton and silk can confirmed the usage of this plant as dyes. Nowadays, there have been industrial methods available for colour components/purified colour substance from natural dyes for easy applications. This is by collecting source material and dried in an open air or dried under sun within a given temperature range of about $37-40^{\circ} \mathrm{C}$ for the moisture 
content of the source natural dye material to be reduce to $10-15 \%$ with proper drying since most of the material have moisture content of $40-80 \%$ and cannot be stored without drying, which later, grinding is carried out to break down the material into very small units or preferably powder form all the treatment methods (Win \& Swe,2008). Extraction of natural dyes was carried out in aqueous method by cutting source material into smaller unit, dried and grinded into powder form, the colour component was extracted in water by employing a standard process(Samanta, Konar Chokroborty, \& Datta, 2010 \& 2011), also extraction was carried out by using pomegranate peel, the sample was washed thoroughly to removed impurities, it was dried at room temperature, grinded into powder form with the help of grinding machine (Win \&Swe,2008), the sample was weight and soaked in 500mls of the solvent (ethanol/water) in a round bottom flask at a ratio of 40:60, and heated in a water bath at $60^{\circ} \mathrm{C}$ for 60 minutes. The solution was then filtered to obtained crude dyestuff as started by (Win \& Swe, 2008; Goodarzian \& Ekrami, 2010).Therefore, with the development of technology on instruments and modern industrialised methods of extraction improvement can be made for making designs (printing, batik, and tie/dyed).

\section{Extraction Procedure of Colour from the Locust Beans Pods Powder}

The sample powder of about 200grams was soaked in $1.8 \mathrm{mls}$ of water and the solvents (methanol \& ethanol) each overnight to obtained $100 \mathrm{mls}$ of the filtrate colour. Therefore, 800 grams gave $400 \mathrm{mls}$ of the filtrate, which was used to dye the measured fabrics $(50 \times 50$ centimetres), three mordanting treatment methods was used in the dyeing process and a total of $24 \mathrm{~cm}$ each of cotton and silk fabrics were used in this study

\section{Results}

From the Table 1, it can be observed that all the treatment methods have stunning results of excellent to good, fairly well, except the perspiration fastness test in acid and alkaline for both pre-mordant and post-mordant in mordant (A) which was Alum revealed colour loss of $(1 \& 2-3)$ and without mordant has (2) on cotton fabric all in aqueous medium combination.

For Table 2 also revealed excellent to good, fairly well results, except washing fastness results in pre-mordant, post-mordant on cotton, rubbing test pre-mordant on silk fabric have colour loss of (2-3) respectively in methanol medium combination, while in Table 3, the ethanol medium combination have excellent to good, fairly well results, except the light fastness results of pre-mordant on silk fabric only, meanwhile the loss of colour could be due to either, the mordant were not properly bonded with the dye, or the fibres have no good affinity with the mordant, or it could be the acid and alkaline have destroyed the existed bondage during the perspiration fastness test. However, all the results can be acceptable to be used as natural dyes especially on cotton and silk fabrics. 
Table1. Fastness grades of locust beans fruits pods on cotton and silk fabrics at dyeing time of 10 minutes at $100^{\circ} \mathrm{C}$ temperature in aqueous medium combination

\begin{tabular}{|c|c|c|c|c|c|c|c|c|c|c|c|c|c|c|c|c|c|c|c|c|c|}
\hline \multirow{6}{*}{$\begin{array}{l}\text { Mordanting } \\
\text { Method }\end{array}$} & \multirow{6}{*}{$\begin{array}{c}\text { Type of } \\
\text { Mordant } \\
\text { Used }\end{array}$} & \multicolumn{20}{|c|}{ Locust Beans Pod A } \\
\hline & & \multicolumn{10}{|c|}{ Cotton } & \multicolumn{10}{|c|}{ Silk } \\
\hline & & $\begin{array}{l}\text { Light } \\
\text { Grades }\end{array}$ & \multicolumn{2}{|c|}{ Washing } & \multicolumn{3}{|c|}{ Rubbing } & \multicolumn{4}{|c|}{ Derspiration } & $\begin{array}{l}\text { Light } \\
\text { Gradez }\end{array}$ & Wa & & \multicolumn{3}{|c|}{ Fubbing } & \multicolumn{4}{|c|}{ Derspiration } \\
\hline & & & \multicolumn{2}{|c|}{ Orades } & \multicolumn{3}{|c|}{ Orades } & \multicolumn{4}{|c|}{ Orade8 } & & & & \multicolumn{3}{|c|}{ Orades } & \multicolumn{4}{|c|}{ Orades } \\
\hline & & & & & Dry & \multicolumn{2}{|c|}{ Wet } & \multicolumn{2}{|c|}{ Acidic } & \multicolumn{2}{|c|}{ Alkaline } & & & & Dry & \multicolumn{2}{|c|}{ Wet } & \multicolumn{2}{|c|}{ Acidic } & \multicolumn{2}{|c|}{ Alkaline } \\
\hline & & & $\mathrm{CC}$ & $\mathrm{CS}$ & $\mathrm{CC}$ & $\mathrm{CC}$ & CS & $\mathrm{CC}$ & $\mathrm{CS}$ & $\mathrm{CC}$ & CS & & $\mathrm{CC}$ & CS & $\mathrm{CS}$ & $\mathrm{CC}$ & CS & CS & CS & $\mathrm{CC}$ & $\mathrm{CS}$ \\
\hline \multirow{4}{*}{$\begin{array}{c}\text { Pre- } \\
\text { Mordanting }\end{array}$} & A & 4 & 3 & 5 & 5 & & $4-5$ & 1 & $4-5$ & 1 & $4-5$ & 4 & 4 & 5 & 5 & & $4-5$ & $4-5$ & 5 & $4-5$ & 5 \\
\hline & B & $5-6$ & $3-4$ & 4 & $4-5$ & & 4 & 4 & $4-5$ & 4 & $4-5$ & 5 & 3 & 4 & $4-5$ & & 4 & 4 & 5 & 4 & 5 \\
\hline & $\mathrm{C}$ & 6 & $3-4$ & 4 & $4-5$ & & 4 & $3-4$ & 5 & $3-4$ & 5 & 6 & 3 & 5 & 4 & & 4 & $3-4$ & $4-5$ & $3-4$ & $4-5$ \\
\hline & $\mathrm{D}$ & 5 & $4-5$ & 4 & 4 & & 4 & $3-4$ & $4-5$ & 4 & $4-5$ & $5-6$ & 4 & 5 & 4 & & 4 & 3 & $4-5$ & $3-4$ & $4-5$ \\
\hline \multirow{4}{*}{$\begin{array}{l}\text { Simultanecus } \\
\text { Mordanting }\end{array}$} & A & 5 & $4-5$ & 5 & 5 & & $4-5$ & 4 & 4 & $3-4$ & 4 & $5-6$ & 3 & 4 & 5 & & $4-5$ & 4 & 5 & $3-4$ & 5 \\
\hline & B & $5-6$ & $3-4$ & 4 & $4-5$ & & 4 & 4 & 5 & 3 & 4 & 6 & 3 & 4 & $4-5$ & & 4 & 4 & $4-5$ & $3-4$ & $4-5$ \\
\hline & C & $6-7$ & 3 & 4 & $4-5$ & & 4 & 3 & 5 & 3 & 5 & $6-7$ & $3-4$ & 5 & 4 & & 4 & 3 & 5 & $3-4$ & 5 \\
\hline & D & $5-6$ & $3-4$ & $4-5$ & $4-5$ & & 4 & $3-4$ & 5 & 4 & 5 & 5 & 4 & 5 & 4 & & 4 & $4-5$ & 5 & $4-5$ & 5 \\
\hline \multirow{4}{*}{$\begin{array}{c}\text { Dost- } \\
\text { Mordanting }\end{array}$} & A & $4-5$ & 3 & 4 & 5 & & 4 & $2-3$ & $4-5$ & $3-4$ & $4-5$ & $4-5$ & 3 & $4-5$ & $4-5$ & & $4-5$ & 1 & 5 & 1 & 5 \\
\hline & B & 6 & 4 & 5 & $4-5$ & & 4 & 4 & 4 & 3 & 4 & 6 & 3 & 5 & 4 & & 4 & 4 & $4-5$ & 4 & $4-5$ \\
\hline & C & $6-7$ & 3 & $3-4$ & 4 & & 3 & 3 & 4 & 3 & 4 & 7 & 3 & 4 & 4 & & $3-4$ & 3 & 4-5 & 4 & $4-5$ \\
\hline & $\mathrm{D}$ & 5 & 3 & $4-5$ & $4-5$ & & 4 & $3-4$ & 5 & 3 & 5 & 5 & 3 & $4-5$ & $4-5$ & & 4 & 3 & 5 & $3-4$ & $4-5$ \\
\hline $\begin{array}{l}\text { Without } \\
\text { Mordanting }\end{array}$ & & 4 & $3-4$ & 4 & 5 & & 4 & 3 & $4-5$ & 3 & 4 & 4 & 2 & $3-4$ & $4-5$ & & $4-5$ & 3 & $4-5$ & 3 & 5 \\
\hline
\end{tabular}

Table 2. Fastness grades of locust beans fruits pods extract on cotton and silk fabrics at dyeing time of 10 minutes at $100^{\circ} \mathrm{C}$ temperature in methanol medium combination

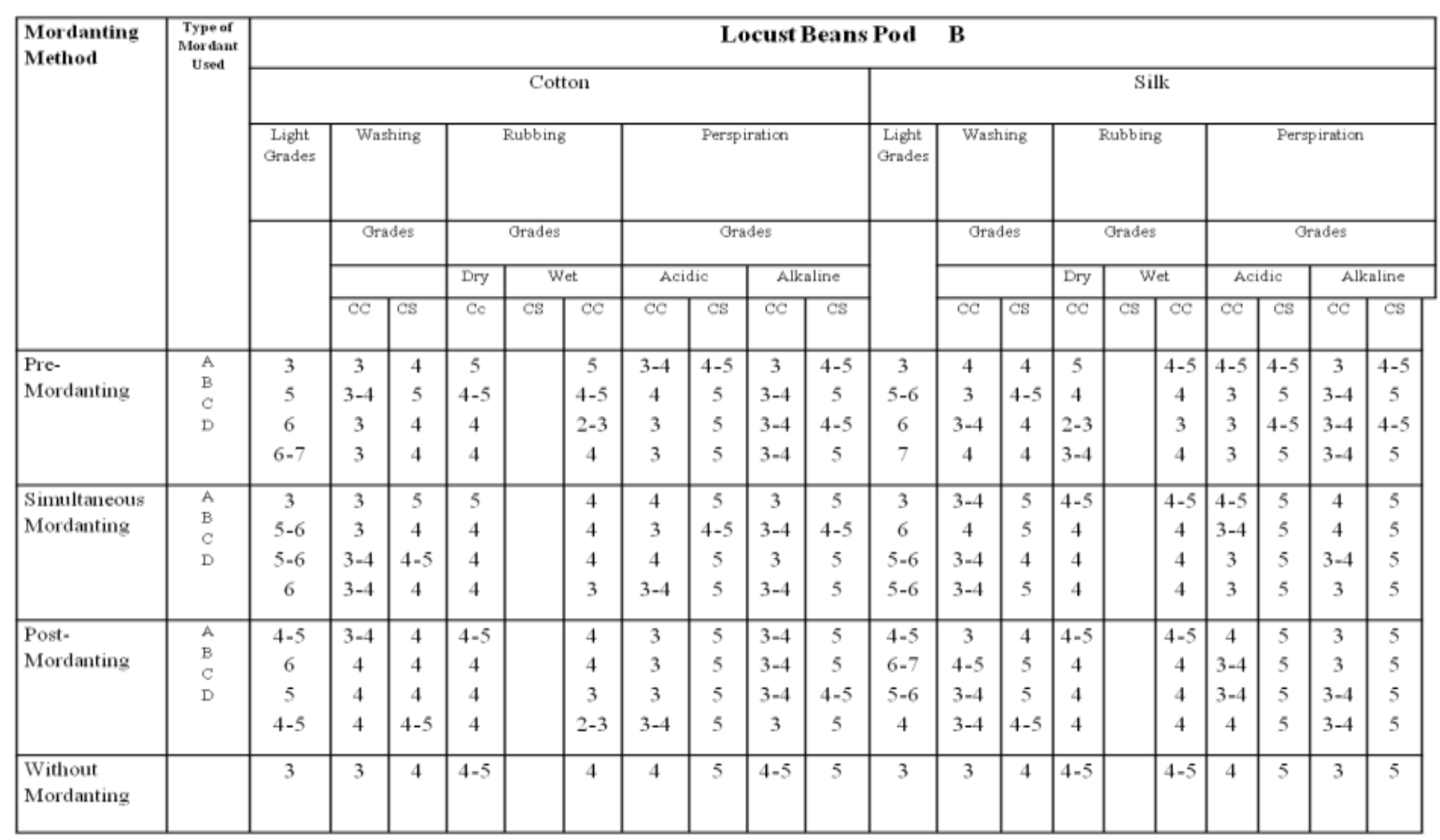




\section{Ml Macrothink}

Table 3. Fastness grades of locust beans pod on cotton and silk fabrics at dyeing time of 10 minutes at $100^{\circ} \mathrm{C}$ temperature in ethanol medium combination

\begin{tabular}{|c|c|c|c|c|c|c|c|c|c|c|c|c|c|c|c|c|c|c|c|c|c|}
\hline \multirow{6}{*}{$\begin{array}{l}\text { Mordanting } \\
\text { Method }\end{array}$} & \multirow{6}{*}{$\begin{array}{c}\text { Type of } \\
\text { Mordant } \\
\text { Used }\end{array}$} & \multicolumn{20}{|c|}{ Locust Beans Pod } \\
\hline & & \multicolumn{10}{|c|}{ Cotton } & \multicolumn{10}{|c|}{ Silk } \\
\hline & & \multirow[t]{4}{*}{$\begin{array}{l}\text { Light } \\
\text { Grades }\end{array}$} & \multicolumn{2}{|c|}{ Washing } & \multicolumn{3}{|c|}{ Rubbing } & \multicolumn{4}{|c|}{ Perspiration } & $\begin{array}{ll}\text { Light } \\
\text { Grades }\end{array}$ & \multicolumn{2}{|c|}{ Washing } & \multicolumn{3}{|c|}{ Rubbing } & \multicolumn{4}{|c|}{ Perspiration } \\
\hline & & & \multicolumn{2}{|c|}{ Grades } & \multicolumn{3}{|c|}{ Grades } & \multicolumn{4}{|c|}{ Grades } & & \multicolumn{2}{|c|}{ Grades } & \multicolumn{3}{|c|}{ Grades } & \multicolumn{4}{|c|}{ Grades } \\
\hline & & & & & Dry & \multicolumn{2}{|c|}{ Wet } & \multicolumn{2}{|c|}{ Acidic } & \multicolumn{2}{|c|}{ Alkaline } & & & & Dry & \multicolumn{2}{|c|}{ Wet } & \multicolumn{2}{|c|}{ Acidic } & \multicolumn{2}{|c|}{ Alkaline } \\
\hline & & & $\mathrm{CC}$ & $C S$ & $\mathrm{CC}$ & $C S$ & $\mathrm{CO}$ & $\mathrm{CO}$ & $C S$ & $\mathrm{CC}$ & $C S$ & & $\mathrm{CC}$ & $C S$ & $\mathrm{CC}$ & $C S$ & $C \mathrm{CO}$ & $\mathrm{CO}$ & $C S$ & $\mathrm{CC}$ & $C S$ \\
\hline \multirow{4}{*}{$\begin{array}{l}\text { Pre- } \\
\text { Mordanting }\end{array}$} & A & 3 & 3 & $4-5$ & 5 & & 4 & 3 & 5 & 3-4 & 5 & $2-3$ & 3 & 4 & $4-5$ & & $4-5$ & 4 & 5 & $4-5$ & 5 \\
\hline & B & 5 & 4 & 4 & $4-5$ & & 4 & 4 & 5 & 3 & 5 & 6 & 3 & $4-5$ & 4 & & 4 & 4 & $4-5$ & 3 & $4-5$ \\
\hline & $\mathrm{C}$ & $5-6$ & $3-4$ & 5 & 4 & & $3-4$ & $3-4$ & 5 & $3-4$ & 5 & $5-6$ & $3-4$ & 5 & 3 & & 3 & $3-4$ & 5 & 3 & 5 \\
\hline & D & $5-6$ & 4 & 4 & $4-5$ & & 4 & 3 & 5 & $3-4$ & 5 & 6 & $3-4$ & 4 & 4 & & 4 & 3 & 5 & $3-4$ & 5 \\
\hline \multirow{4}{*}{$\begin{array}{l}\text { Simultaneous } \\
\text { Mordanting }\end{array}$} & A & 3 & 3 & $4-5$ & 5 & & $4-5$ & 3 & 5 & 3 & 5 & 3 & 3 & 5 & 5 & & $4-5$ & 4 & 5 & 4 & 5 \\
\hline & B & $5-6$ & $3-4$ & 4 & $4-5$ & & 4 & 3 & 4 & $3-4$ & 4 & 6 & 4 & $4-5$ & 4 & & 4 & 4 & 5 & $3-4$ & 5 \\
\hline & C & 5 & $3-4$ & 4 & $4-5$ & & 4 & 3 & 5 & 3 & 5 & $4-5$ & 3 & 4 & $4-5$ & & 4 & 3 & 5 & $3-4$ & 5 \\
\hline & D & $5-6$ & 3 & 4 & 4 & & $3-4$ & $3-4$ & 5 & $3-4$ & 5 & $3-4$ & 3 & 5 & 4 & & 4 & $3-4$ & $4-5$ & 3 & $4-5$ \\
\hline \multirow{4}{*}{$\begin{array}{l}\text { Post- } \\
\text { Mordanting }\end{array}$} & $\mathrm{A}$ & 4 & 3 & 4 & 5 & & 4 & $3-4$ & 4 & 4 & 4 & 3 & 4 & 5 & 4 & & 5 & $4-5$ & 5 & 4 & 5 \\
\hline & B & 7 & 4 & 4 & 4 & & 4 & 4 & 5 & 4 & $4-5$ & $6-7$ & 4 & 5 & 4 & & 4 & 4 & $4-5$ & $4-5$ & $4-5$ \\
\hline & $\mathrm{C}$ & $5-6$ & $3-4$ & 4 & $4-5$ & & 4 & $3-4$ & 5 & 4 & 5 & 5 & 3 & 5 & $4-5$ & & 4 & $3-4$ & 5 & $3-4$ & 5 \\
\hline & D & 4 & 3 & $4-5$ & 5 & & 4 & 3 & 5 & $3-4$ & 5 & 5 & 3 & 5 & 4 & & 4 & 4 & 5 & $3-4$ & 5 \\
\hline $\begin{array}{l}\text { Without } \\
\text { Mordanting }\end{array}$ & & $3-4$ & 4 & $4-5$ & 5 & & 4 & 4 & 5 & $4-5$ & 5 & $3-4$ & 4 & 5 & 5 & & 5 & $3-4$ & 5 & 3 & 5 \\
\hline
\end{tabular}

Key: A- Aluminium Potassium Sulphate

CC- Colour Change

B- Copper (II) Sulphate

CS- Colour Staining

C- Iron (II) Sulphate

D- Iron (III) Sulphate

\section{Conclusion}

The used of the mordant gave different shades to the fabrics, there was wide range of soft and light colors obtained both on cotton \& silk, by using the dye extracted from locust beans fruits pods especially on methanol \& ethanol medium combination. With regards to color fastness, tested samples exhibited excellent to good, fairly well, except that the extract has 6 samples with less than grade value (3) in aqueous combination. In methanol combination, it has 3 that were less than grade value (3).In ethanol combination; it has only 1 sample that was less than grade (3).

However, the extracts is a good natural dyes, so recommend to be use as dyes, to textiles industries, institutions that deals with dyes/coloring, organizations, the government. Also from the results it was revealed that the Locust beans extract have 10 samples with grade value less than (3).

\section{Findings and Future Work}

From the investigation it was revealed that the extract was good use as natural dyes, so can be accepted by dyeing industries as well as local dyers and that plants is abundance, therefore, our unemployed youths can have something to do, farmers also can expand their cultivation, 
consequently market business will be generated in that direction, further investigation can be done with other types of mordant and natural fabrics such as chrome, stannous chloride, potash, lemon juice and wool, jute, etc respectively.

\section{References}

Adeel, S., Ali, S., Bhatti, I. A., \& Zsila, F. (2009). Dyeing of cotton fabric using pomegranate (Punica granatum) aqueous extract. Asian Journal of Chemistry, 21(5); 3493-3499. Universal journal of Research and technology, 1(2), 135-139.

Akande, F. B., \& Adejumo, O. A. et al. (2010). Processing of locust beans fruits, Challenges and Prospects. African Journal of Agricultural Research, 5(17), pp.2268-2271

Goodarzian, H., \& Ekrami, E. (2010). Extraction of dye from madder plant (Rubiatinctorium L), World Applied Science Journal, 9(4), 434-436.

Goodarzian, H., \& Ekrami, E. (2010). Wool dyeing with extraction of dye from Pomegranate (punicagranatum L) peel. World Applied Science Journal, 8(11), 1387-1389. http://earthobservatory.nasa.gov/features/OzoneWeBreathe/ozone

Jimoh, Y. A., \& Adamu, A. (2010). Production and classification of locust beans pod ash (LBPD) as a pozzolan. Retrieved 11 April, 2012, from http://www-engineering civil.com/ production-and-classification-L

Jeannie, A. (2002). The ozone we breath. Retrieved 11 April, 2012, http://earthobservatory. nasa.gov/features/ozone

Nishinari, K., \& Takemasa, M. et al. (2007). An answer to Africa's greatest needs in one tree (locust beans). Retrieved 6 April, 2012, http:/ blogs. World waych.org/ nourishing the planet/the-locust-beans-an.

Mantazer, M., \& Parvinzadeh, M. (2007). Dyeing of wool with Marigold and its properties, fibres and polymer. 8(2), 181-185. Universal journal of Environmental Research and technology, 1(2), 135-139.

Onal, A. (1996). Extraction of dyestuff from madder plant (Rubia tinctorum L.) and dyeing of Wool, feathered-Leather and cotton. Turkish Journal of Chemistry, 20, 204-214.

Pruthi, N., Chawla, G., \& Yadav, S. (2008). Dyeing of silk with barberry bark dye using mordant combination. National product Radiance, 7(1); 40-44.,

Samanta, A. K., Konar, A., Chokroborty, S., \& Datta, S. (2010). Extraction of colour from Madder at alkali conditions under aqueous medium. Journal Institution of Textile Engineering, Textile Engineering Division, India.

Samanta, A. K., Konar, A., Chokroborty, S., \& Datta, S. (2011). Extraction of colour from tesu (palash flower) in acid, $\mathrm{PH}$, condition in aqueous medium. Journal Institution of Engineering, Textile Engineering Division India.

Samanta, A. K., \& Agarwal, P. (2009). Application of natural dyes on textiles. Universal 


\section{Macrothink \\ Environmental Management and Sustainable Development \\ ISSN 2164-7682 2013, Vol. 2, No. 1}

Journal of Environmental Research and Technology, 34, 384-399.

Saha, P., \& Dutt, S. (2004). Production of floral Dyes from Different flowers Available in West Bangal for Textiles and dyeing Industry. Retrieved 6 April, 2012, http://www.chemca 2007.com

Shariff, A. (2010). Extraction of natural colorants from onion (a) skin using pressurized liquid extraction for application in fabric dyeing. Master's thesis.

Win, \& Swe, (2008). Drying of Natural dyes in an oven using drying Machine. Academy of science, Engineering \& Technology, 46, 536-540

Zhong, Y. C., Sun, M., \& Clarke, H. (2005). Characterization and application of betalain pigments from plants of the amaranthaleae. Trends of Food Science Technology, 16, 370-376.

\section{Copyright Disclaimer}

Copyright reserved by the author(s).

This article is an open-access article distributed under the terms and conditions of the Creative Commons Attribution license (http://creativecommons.org/licenses/by/3.0/). 